\title{
PERAN KEBIJAKAN EKSPORT PEMERINTAH TERHADAP PROSES INTERNASIONALISASI UMKM
}

\author{
Lusia P.S Hartanti \\ Lulu Setiawati \\ Email: lusiapsh@yahoo.com ${ }^{1} \underline{\text { lulu.setiawati@uphsurabaya.ac.id }}^{2}$
}

\section{Penulis}

Lusia P.S Hartanti adalah Dosen pada Program Studi Akuntansi Universitas Pelita Harapan Surabaya dengan peminatan bidang Manajemen Keuangan.

Lulu Setiawati adalah Dosen dan Kepala Program Studi Akuntansi Universitas Pelita Harapan Surabaya dengan peminatan bidang Manajemen Keuangan

\section{Abstract:}

Small and Medium Enterprises is one of locomotion the economy in Indonesia. It amounted to 56,5 millions units, whereas $99.8 \%$ of them are in the micro sector business. This thing causes government have to think the way to help small entrepreneurs to ease their business. INSW is Indonesia's national system which allows making acceleration in import-export process. Research method which is used in this research is case study. Data collected through interviews with small entrepreneur. The results of the study found that small entrepreneurs have not understood and take advantage of the policy that has been determined by the government. They hope that . Para pelaku bisnis mengharapkan the Government to be more proactive about INSW's policy of socialization do who have been there, so they can exploit it.

\section{Kata Kunci}

Usaha Kecil Menengah, INSW, ekspor-impor

\section{PENDAHULUAN}

UKM merupakan salah satu penggerak perekonomian di Indonesia. Jumlah UKM di Indonesia mencapai sekitar 56,5 juta, dimana 99,8\% adalah usaha mikro, kecil dan menengah (UMKM). Kontribusi koperasi dan UMKM terhadap pendapatan 
domestik bruto (PDB) Indonesia adalah 66\% (www.depkop.go.id). Hal ini menunjukkan bahwa sektor UKM memberikan kontribusi yang baik bagi perekonomian Indonesia.

Produk-produk yang dihasilkan oleh UMKM tidak hanya dapat dipasarkan didalam negeri namun juga di pasar internasional. Kesempatan memasuki pasar internasional akan mendorong UMKM untuk mengalami pertumbuhan dan perkembangan. Namun demikian, UKM juga harus dapat mempersiapkan diri mereka dengan baik agar mampu bersaing, bertahan dan berkembang di pasar internasional. Salah satu indikator perusahaan mengalami pertumbuhan adalah melakukan ekspansi ke luar negeri atau pasar internasional (Dunning \& Lundan, 2008 dalam Jane, 2012).

Pasar internasional memberikan kesempatan kepada setiap pelaku usaha untuk mencari dan memperluas pangsa pasar. Berbagai persiapan perlu dilakukan oleh UKM agar dapat masuk ke dalam pasar internasional. Proses internasionalisasi merupakan sebuah konsep yang dinamis yaitu proses meningkatkan operasi internasional, baik pada keluar maupun kedalam (Welch \& Luostarien, 1988 dalam Jane, 2012). Proses internasionalisasi adalah proses dimana perusahaan meningkatkan baik kesadaran mereka mengenai pengaruh langsung maupun tidak langsung transaksi internasionalnya di masa yang akan datang dan mendirikan serta melaksanakan transaksi dengan negara lain (Beamish,1990 dalam Jane, 2012).

Faktor-faktor utama yang menentukan besar kecilnya peluang perusahaan adalah: (a) akses sepenuhnya ke informasi mengenai aspek-aspek kunci bagi keberhasilan suatu usaha seperti kondisi pasar yang dilayani dan peluang pasar 
potensial, teknologi terbaru/terbaik yang ada di dunia, sumber-sumber modal dan cara pembiayaan yang paling efisien, mitra kerja (b) akses ke teknologi terkini/terbaik; (c) akses ke modal, (d) akses ke tenaga terampil/SDM, (e) akses ke bahan baku, (f) infrastruktur, (g) kebijakan atau peraturan yang berlaku, baik dari pemerintah sendiri maupun negara mitra (misalnya kesepakatan bilateral) dan yang terkait dengan WTO, AFTA, APEC, dan lain-lain (Tambunan, 2012).

Peranan pemerintah dalam mendukung UMKM melakukan proses internasionalisasi sangatlah penting. Kebijakan ini membantu para pelaku UMKM agar dapat melakukan ekspor, mendorong meningkatkan komoditas ekspor dan juga melindungi para pelaku UMKM agar mampu bersaing dengan produkproduk lainnya. Pemerintah melalui Kementerian Koperasi dan UKM menyusun lima langkah kebijakan bagi pemberdayaan secra optimal koperasi dan usaha mikro, kecil dan menengah hingga 2014 yang terkait dengan rencana pembangunan jangka panjang. Kebijakan tersebut adalah meningkatkan iklim usaha kondusif bagi KUMKM, mengembangkan produk pemasaran KUMKM, mengembangkan produk dan pemasaran bagi KUMKM, peningkatan daya saing Sumber Daya Manusia KUMKM, serta perkuatan kelembagaan koperasi (http://industri.bisnis.com).

Indonesia National Single Window (INSW). INSW merupakan Sistem nasional Indonesia yang memungkinkan dilakukannya suatu penyampaian data dan informasi secara tunggal (single submission of data and information), pemrosesan data dan informasi secara tunggal dan sinkron (single and synchronous processing of data and information), dan pembuatan keputusan secara tunggal untuk pemberian izin kepabeanan dan pengeluaran barang (single 
decision making for customs clearance and release of cargoes) (Peraturan Presiden Nomor 10 Tahun 2008). Sistem INSW harus diaplikasikan oleh seluruh pelaku usaha yang melakukan proses ekspor-impor, termasuk juga UMKM. Menghadapi era perdagangan bebas dan terbuka, UKM harus mempersiapkan diri sehingga mampu bersaing dengan perusahaan-perusahaan lainnya. INSW sebagai salah satu yang dirancang oleh pemerintah diharapkan mampu mendorong proses ekspor-impor agar berjalan lebih efektif dan efisien.

Tujuan penelitian ini adalah mengetahui penerapan INSW pada pelaku

\section{UMKM}

\section{METODE PENELITIAN}

Prosedur yang akan dilakukan dalam penelitian ini adalah sebagai berikut:

1. Identifikasi Masalah

Identifikasi masalah merupakan langkah awal dalam penelitian ini. Permasalahan yang akan diteliti adalah Efektifitas kebijakan pemerintah dalam mendukung produk ekspor UKM dan strategi UKM dalam menghadapi proses internasionalisasi.

2. Penetapan Tujuan Penelitian

Penetapan tujuan penelitian bertujuan agar penelitian yang dilakukan mengarah pada sasaran yang tepat. Tujuan penelitian ini adalah untuk mengetahui efektifitas kebijakan pemerintah dalam mendukung produk ekspor UKM dan menyusun strategi UKM dalam menghadapi proses internasionalisasi.

3. Pengumpulan Data

Pengumpulan data dalam penelitian ini dilakukan dengan cara studi literatur dan wawancara 
Studi Literatur: mempelajari penelitian-penelitian terdahulu sebagai pendukung pencapaian tujuan dalam penelitian ini. Sumber Literatur yang akan digunakan dalam penelitian ini berasal buku, jurnal, artikel, laporan pemerintah, hasilhasil peneltian dan data-data lainnya yang terkait.

Wawancara: wawancara dilakukan pada pelaku UKM, pejabat instansi pemerintah dan pakar ekonomi.

4. Pengolahan dan Analisis Data

Penelitian ini menggunakan metode review literature. Review literature merupakan deskripsi dari literatur yang relevan pada topik khusus, dimana akan memberikan gambaran secara menyeluruh atas topik yang terkait (Jane, 2012). Selain melakukan Review literature juga dilakukan studi kasus dengan para pelaku UKM, Pejabat instasi pemerintah dan pakar ekonomi. Metode wawancara dilakukan dengan cara depth interview dimana peneliti bertemu langsung dengan responden dan melakukan wawancara tatap muka. Selama proses wawancara tersebut, pengumpulan data dilakukan dengan cara peneliti menanyakan beberapa item pertanyaan dan responden akan memberikan jawabannya. Hal ini dilakukan dengan harapan agar peneliti dapat memperoleh informasi yang banyak dan akurat dari pertanyaan yang ada. Hasil dari wawancara tersebut akan berupa narasi statement yang nantinya akan mendukung studi literatur yang ada.

5. Penarikan Kesimpulan

Berdasarkan hasil analisis data maka akan dapat ditarik suatu kesimpulan yang akan menjawab permasalahan yang ada. Diharapkan hasil kesimpulan tersebut dapat memberikan baik manfaat teoritis maupun empiris, dimana manfaat 
teoritis adalah kemampuan hasil penelitian ini mendukung studi literatur yang ada dan manfaat empirisnya adalah memberikan masukkan kepada pihak-pihak yang terkait, antara lain pemerintah dan pakar ekonomi didalam merumuskan kebijakan baru selanjutnya.

\section{HASIL DAN PEMBAHASAN}

\section{Indonesia National Single Window (INSW) Policy}

Peraturan Presiden Nomor 10 Tahun 2008 mengemukakan mengenai Sistem Nasional Indonesia yang memungkinkan dilakukannya suatu penyampaian data dan informasi secara tunggal (single submission of data and information), pemrosesan data dan informasi secara tunggal dan sinkron (single and synchronous processing of data and information), dan pembuatan keputusan secara tunggal untuk pemberian izin kepabeanan dan pengeluaran barang (single decision making for customs clearance and release of cargoes).

Tujuan diterapkannya INSW adalah untuk melakukan percepatan dalam penyelesaian proses ekspor-impor serta peningkatan efektifitas dan kinerja penanganan atas lalu lintas barang ekspor impor. Implementasi INSW dilakukan melalui portal INSW, sistem elektronik yang dapat diakses melalui jaringan internet dan ter-integrasi secara nasional, yang akan melakukan integrasi informasi berkaitan dengan proses penanganan dokumen kepabeanan dan dokumen lain yang terkait dengan ekspor-impor, yang menjamin keamanan data dan informasi serta memadukan alur dan proses informasi antar sistem internal secara otomatis, yang meliputi sistem kepabeanan, perizinan, kepelabuhanan/ kebandarudaraan, dan sistem lain yang terkait dengan proses pelayanan dan pengawasan kegiatan ekspor-impor.

\section{Penerapan INSW di UMKM}


UMKM pesantren Mukmin Mandiri Sidoarjo dipimpin oleh Bapak Drs. H. Muhammand Zakki, M.Si. Bisnis yang diterapkan di pesantren tersebut salah satunya adalah produksi kopi, dengan merek "Mahkota Raja Blend Doa". Visi dari pesantren tersebut adalah santri berwawasan wirausahawan dan usahawan yang berjiwa santri, sedangkan misinya adalah mendidik dan mencetak santri menjadi wirausahawan yang saleh dan mandiri.

Para santri yang ada disana mengolah kopi, mulai dari biji kering hingga menjadi roster/bubuk. Kopi tersebut kemudian diekspor baik di Asia, Amerika maupun Eropa. Penjualanannya mencapai 30-35 ton per bulan. Pesantren ini merupakan Pesantren Agrobisnis dan Agroindustri. Sebuah Pesantren Agrobis yang bergerak pada komoditas Kopi Roaster (Kopi Goreng), Kopi Bubuk dan Kopi Sachet, dimana dikelola secara mandiri ole para Santri

UMKM merupakan sebagai salah satu penggerak ekonomi bangsa, dimana proses perdaganggannya dapat dilakukan didalam dan di luar negeri. Pesantren Mukmin Mandari adalah salah satu UMKM yang melakukan perdagangan pada tingkat internasional dengan komoditas utama berupa kopi. Ada beberapa hal utama yang diperhatikan oleh pesantren tersebut dalam melakukan pemasaran produknya ditingkat internasional, antara lain menjaga kualitas dan konsistensi pasokan produk dan pengiriman tepat waktu.

Pemahaman aturan ekspor-impor memiliki peranan yang penting dalam mendukung proses pemasaran di luar negeri. Salah satu kebijakan yang diterapkan oleh pemerintah adalah terkait system INSW. Berdasarkan wawancara yang dilakukan kepada pemilik Pesantren diketahui bahwa sistem INSW telah diketahui. Menurutnya INSW diharapkan dapat membantu para pengusaha dalam melakukan ekspor-impor sehingga 
tidak terdapat lagi proses yang berbelit-belit. Informasi terkait INSW belum diketahui dan dipahami oleh sepenuhnya oleh pelaku UMKM. Hal ini disebabkan kurangnya sosialisasi dan pelatihan yang diadakan pemerintah terkait INSW. Selain itu, kurangnya kemampuan sumber daya manusia dalam melaksanakan INSW dan sistem manajemen yang dimiliki oleh UMKM pada umumnya relatif masih tradisonal. Menurut Tambunan (2008), hendaknya keahlian yang dimiliki pekerja tidak hanya dalam teknik produksi tetapi juga teknik pemasaran dan dalam penelitian dan pengembangan (R\&D), sedangkan keahlian pengusaha terutama adalah wawasan bisnis.

Tambunan (2008) mengemukakan daya saing dari UKM ditentukan oleh tujuh faktor yang sangat penting yaitu keahlian atau tingkat pendidikan pekerja, keahlian pengusaha, ketersediaan modal, sistem organisasi dan manajemen yang baik (sesuai kebutuhan bisnis), ketersediaan teknologi, ketersediaan informasi, dan ketersediaan inputinput lainnya seperti enerji, bahan baku, dll.

\section{Strategi}

Keberhasilan didalam menerapkan INSW akan bergantung kepada usaha-usaha pemerintah dalam menunjang keberhasilan program tersebut. Langkah yang sudah dilakukan oleh pemerintah saat ini dengan membuat portal khusus mengenai INSW adalah sudah tepat, namun akan menjadi lebih baik bila sosialisasi tersebut tidak hanya melalui portal yang ada, tetapi juga didukung dengan aktivitas pendekatan langsung kepada pelaku bisnis, antara lain dengan lebih sering berinteraksi dengan mereka melalui workshop dan seminar. Sumber daya manusia juga perlu dipersiapkan oleh pemerintah dengan memberikan pelatihan-pelatihan kepada orang-orang yang ditunjuk sebagai bagian dari operasional kegiatan INSW tersebut. 


\section{SIMPULAN}

Penetapan Indonesia Single Window Policy yang dilakukan oleh pemerintah adalah merupakan persiapan pemerintah didalam mempermudah pengusaha didalam melakukan bisnis mereka. Kebijakan tersebut pada dasarnya sangat bermanfaat bagi para pelaku bisnis tujuan diterapkannya INSW adalah untuk melakukan percepatan dalam prosedur ekspor-impor serta meningkatkan efektifitas dan kinerja penanganan atas lalu lintas barang di pelabuhan. Namun yang cukup disayangkan oleh para pengusaha adalah proses sosialiasi yang dilakukan oleh pemerintah masih belum mencukupi. Pemerintah diharapkan untuk dapat lebih proaktif didalam memperkenalkan peraturan mengenai INSW tersebut, sehingga dapat dimanfaatkan oleh para pelaku bisnis dengan lebih maksimal.

\section{DAFTAR PUSTAKA}

Jane, Orpha. 2012. Proses Internasionalisasi Perusahaan : Desain Strategi \& Organisasi (Studi kasus UMKM di Kota Bandung). Lembaga Penelitian dan Pengabdian kepada Masyarakat. Universitas Katolik Prahayangan

Keputusan Presiden Republik Indonesia (Kepres Ri) No. 99 Tahun 1998 Tentang Bidang/Jenis Usaha Yang Dicadangkan Untuk Usaha Kecil Dan Bidang/Jenis Usaha Yang Terbuka Untuk Usaha Menengah Atau Usaha Besar Dengan Syarat Kemitraan

Peraturan Presiden Nomor 10 Tahun 2008

Setyobudi, Andang. 2007. Peran Serta Bank Indonesia dalam Pengembangan Usaha Mikro, Kecil dan Menengah (UMKM), Buletin Hukum Perbankan dan Kebanksentralan 5, 29-35. 
Tambunan, Tulus T.H. 2012. Peluang, Tantangan Dan Ancaman Bagi Umkm Indonesia Dalam Era Cafta Dan Me-Asean 2015.

Undang-Undang Republik Indonesia no. 20 tahun 2008 tentang Usaha Mikro, Kecil dan Menengah

www.depkop.go.id

www.insw.go.id 